\title{
Identification of specific FSH binding sites in the testes of adult monkeys of different species
}

\author{
M. I. Berman and M. R. Sairam \\ Reproduction Research Laboratory, Clinical Research Institute of Montreal, 110 Pine Avenue West, \\ Montreal, Quebec H2W 1R7, Canada
}

\begin{abstract}
Summary. The interaction of ${ }^{125} \mathrm{I}$-labelled hFSH with primate testicular tissue from 4 species of adult monkeys (Macaca mulatta, M. nemestrina, $M$. fascicularis and Papio cynocephalus) was investigated. ${ }^{125}$ I-labelled hFSH binding to a particulate fraction $(\mathrm{P} 1,40000 \mathrm{~g})$ of frozen testes was highly specific and saturable. Displacement curves generated using the P1 fraction of testes from the 4 species and ${ }^{125} \mathrm{I}$-labelled hFSH and unlabelled FSH were very similar. The binding of FSH to the monkey testicular receptor was not species specific because purified FSH from heterologous species such as horse, sheep, pig and rat were very effective in competing with ${ }^{125} \mathrm{I}$-labelled hFSH for binding. The equine FSH was about 10 times more active than hFSH in this respect. Similarly, ${ }^{125}$ I-labelled ovine FSH bound as well as labelled hFSH to the testes fractions of all 4 monkey species. In marked contrast to the high binding of ${ }^{125} \mathrm{I}$ labelled hFSH, binding of ${ }^{125}$ I-labelled hCG with rhesus monkey testis homogenates and $\mathrm{P} 1$ fractions was very low. The FSH receptor in the adult rhesus monkey testis was present in much larger quantity than the $\mathrm{LH}$ receptor and was more readily detectable. Our studies show that frozen primate testis can be utilized for investigating testicularFSH interactions.
\end{abstract}

\section{Introduction}

The mechanism of action of gonadotrophic hormones in laboratory animals has been extensively investigated by in-vivo and in-vitro methods. Consistent with the idea that the first step in the mechanism of action of peptide hormones is their binding to the cell membrane, the presence of surface receptors for gonadotrophins has been demonstrated in ovarian and testicular tissue from many species (for review, see Ryan \& Lee, 1976; Dufau \& Catt, 1978). Specific binding sites for hCG (LH) have been demonstrated for monkey (Davies, Walsh, Hodgen, Dufau \& Catt, 1979) and human (Frowein \& Engel, 1974; Huhtaniemi, Korenbrot \& Jaffe, 1977; Hsu, Stratico, Hosaka \& Troen, 1978; Davies et al., 1979; Sharpe, Wu \& Hargreave, 1980) testes. These receptors are similar in many respects to the testicular hCG/LH receptor of other animals (Davies et al., 1979). However, little is known about specific FSH binding sites (receptors) in human or monkey testes. Most of the available data on the testicular FSH receptor comes from studies with rats (Means \& Vaitukaitis, 1972; Bhalla \& Reichert, 1974) and domestic species such as cattle (Cheng, 1975a, b; Abou-Issa \& Reichert, 1977) and pig (Rogister et al., 1978). FSH has been shown to be essential for the spermatogenic process of the adult monkey (Murty, Sheela Rani \& Moudgal, 1980; MadhwaRaj, Sairam \& Nieschlag, 1980). We have therefore been studying the characteristics of primate gonadotrophin receptors, and the present report relates to the demonstration and preparation of high-affinity specific binding sites for human FSH (hFSH) in four non-human primate species. Preliminary results for the rhesus monkey FSH receptor have been reported (Berman \& Sairam, 1982a). 


\section{Materials and Methods}

Hormones and chemicals. Highly purified human FSH (hFSH) and its subunits (Sairam \& Li, 1979), ovine FSH (oFSH) (Sairam, 1979a) and ovine LH (oLH) (Sairam, 1976) were prepared in this laboratory. The hCG (CR-119) and purified rat FSH (iodination grade) were supplied by the National Hormone and Pituitary Program, National Institutes of Health, Bethesda, Maryland, U.S.A. Human TSH, LH and GH were purified in this laboratory (Sairam, Chrétien \& Li, 1978). Ovine prolactin was supplied by Dr C. H. Li, University of California, San Francisco, CA, U.S.A. Purfified equine FSH was obtained from Dr T. Landefeld (University of Michigan, Ann Arbor) and porcine FSH from Dr R. J. Ryan (Mayo Clinic, Rochester, NY, U.S.A.). Highly purified bovine TSH was a gift of Dr J. G. Pierce (University of California, Los Angeles, CA, U.S.A.).

Bovine serum albumin (BSA) and lactoperoxidase were obtained from Sigma, St Louis, MO, U.S.A. All other chemicals were of reagent grade obtained from Fisher Scientific Co., Montreal.

Primate testes. Testes were obtained from rhesus (Macaca mulatta), pig-tailed (Macaca nemestrina), and Japanese crab-eating (Macaca fascicularis) macaques and yellow baboons (Papio cynocephalus). Testes collected at surgery were frozen on solid $\mathrm{CO}_{2}$ with minimum delay and shipped to us from the Regional Primate Research Center at the University of Washington, Seattle, WA, U.S.A. Frozen testes of adult rhesus monkeys removed at castration were also obtained from Emory University, Atlanta, GA, U.S.A. After arrival in the laboratory they were stored at $-70^{\circ} \mathrm{C}$ until use. The approximate ages of the monkeys and identification were provided by the institution sending the samples.

Preparation of subcellular fractions. The decapsulated testes were thawed under a stream of cold air and all subsequent steps were performed at $4{ }^{\circ} \mathrm{C}$. The testes were minced with scissors, rinsed and suspended in $25 \mathrm{~mm}$-Tris- $\mathrm{HCl}, \mathrm{pH} 7.2$ buffer containing $0.1 \mathrm{M}$-sucrose $(5 \mathrm{ml} / \mathrm{g}$ tissue). One testis from each of the four species was homogenized by a hand-held ground-glass tissue grinder using 8 strokes (up and down). The other tissues were individually homogenized mechanically using a Tekmar tissuemizer, set at low speed using 2-3 short pulses lasting 10-15 sec. The homogenate was filtered through 4 layers of cheesecloth and the filtrate was centrifuged at low speed $(600 \mathrm{~g})$ in a Beckman $\mathrm{J} 21 \mathrm{~B}$ centrifuge to remove cellular debris. As the amount of debris eliminated was usually small in the first few experiments, this step was omitted in the subsequent studies without significantly affecting the results. The filtered homogenate $\mathrm{H} 1$ was then centrifuged at $40000 \mathrm{~g}$ for $\mathrm{l} \mathrm{h}$ and the supernatant from this was further subjected to ultracentrifugation at $140000 \mathrm{~g}$ for $1 \mathrm{~h}$. The resultant pellets, designated P1 and P2 respectively, were resuspended by mechanical dispersion using 8 strokes in a tightly fitting glass Dounce homogenizer ( $1 \mathrm{~g} / 2 \mathrm{ml} 25 \mathrm{~mm}-\mathrm{Tris}-\mathrm{HCl}, \mathrm{pH} 7 \cdot 2$ containing $10 \mathrm{~mm}-\mathrm{MgCl}_{2}$ ). The pellets were stored in small aliquots at $-70^{\circ} \mathrm{C}$. Before assay, the fractions were again gently homogenized in the assay buffer to obtain a uniform suspension (see below).

For comparison with the primate receptor, an FSH receptor preparation from adult bull testes was prepared (Sairam, 1979b). An LH-FSH receptor preparation was also prepared by homogenizing adult rat testes in $25 \mathrm{mM}$-Tris- $\mathrm{HCl}, \mathrm{pH} 7.2$ containing $0.1 \mathrm{M}$-sucrose $(5 \mathrm{ml} / \mathrm{g})$. The homogenate was centrifuged at $20000 \mathrm{~g}$ and washed and resuspended in $25 \mathrm{~mm}-\mathrm{Tris}-\mathrm{HCl}, \mathrm{pH} 7 \cdot 2$ with addition of $10 \mathrm{mM}-\mathrm{MgCl}_{2}(2 \mathrm{ml} / \mathrm{g})$.

Protein estimation. To assess protein content, $100 \mu \mathrm{l}$ samples of each subcellular fraction were mixed with $100 \mu \mathrm{l} 0.5 \mathrm{~N}-\mathrm{NaOH}$ and kept in a boiling waterbath. After $30 \mathrm{~min}, 100 \mu \mathrm{l} 0.5 \mathrm{~N}-\mathrm{HCl}$ were added and the protein content was determined using the Bio-Rad protein determination kit (Bio-Rad, Richmond, CA, U.S.A.), and bovine serum albumin as standard.

Labelling of hormones. The hFSH, hCG, hLH, oLH and oFSH were labelled with ${ }^{125}$ I by the lactoperoxidase method (Thorell \& Johansson, 1971) as previously described (Sairam, 1979b), using carrier-free $\mathrm{Na}^{125}$ I (Amersham Inc., Chicago, IL, U.S.A.). The labelled hormones were 
purified by gel filtration on Sephadex G-100 and preserved in aliquots at $-70^{\circ} \mathrm{C}$ until use. They were generally used within 2 weeks of preparation. The specific activities of the labelled hormones were in the range of $50-80 \mu \mathrm{Ci} / \mu \mathrm{g}$.

Binding of ${ }^{125}$ I-labelled gonadotrophins to testicular fractions. The assays of binding of ${ }^{125} \mathrm{I}-$ labelled hormones to each of the testicular subcellular fractions were performed in triplicates in 10 $\times 75 \mathrm{~mm}$ disposable polystyrene tubes. Unless otherwise indicated each tube contained approximately 50000 c.p.m. $(\sim 400 \mathrm{pg}){ }^{125} \mathrm{I}$-labelled hormone, $100-300 \mu \mathrm{g}$ protein equivalent of the testicular fractions and $100 \mu \mathrm{l}$ of the unlabelled hormone and/or assay buffer to constitute a final volume of $250 \mu \mathrm{l}$ per tube. The assay buffer consisted of $25 \mathrm{~mm}-\mathrm{Tris}-\mathrm{HCl}, \mathrm{pH} 7 \cdot 2$ containing $0 \cdot 1 \%$ BSA and $10 \mathrm{~mm}-\mathrm{MgCl}_{2}$. The tubes were vortexed and incubated in a continuously shaking Dubnoff water bath for $2-3 \mathrm{~h}$ at $37^{\circ} \mathrm{C}$. The reaction was terminated by the addition of $2 \mathrm{ml} \mathrm{chilled} \mathrm{assay}$ buffer followed by centrifugation at $2900 \mathrm{~g}$ for $15 \mathrm{~min}$ at $4^{\circ} \mathrm{C}$ in a table-top IEC clinical centrifuge. The supernatant was removed by aspiration under vacuum and the radioactivity in the pellet was determined in an LKB rackgamma II counter (counting efficiency $70 \%$ ). Centrifugation under these conditions was adequate to sediment all of the hormone-receptor complex(es). In the initial studies, precipitation of the supernatant by agents such as polyethylene glycol did not reveal any additional specific binding, and this step was not considered essential in other routine experiments. In all cases, non-specific binding was determined in the presence of a 1000 -fold excess of respective unlabelled hormone. The difference between the total radioactivity bound and non-specific binding was defined as the amount specifically bound and expressed as a percentage of the total counts put into the tubes.

Statistical analysis. Data were analysed for significance by Student's $t$ test. Displacement curves were tested for parallelism using a programmable Hewlett-Packard desk top calculator.

\section{Results}

\section{Distribution of FSH binding sites}

In adult rhesus monkey testes, the amount of protein in the homogenate $(\dot{\mathrm{H}} 1)$ resulting from homogenization by hand or by mechanical dispersion was approximately the same. The distributions in the pellets P1 and P2 were also similar. Operationally, mechanical homogenization was easier and faster than manual glass homogenization and the former was routinely used in more detailed characterization of the rhesus monkey FSH receptor (Berman \& Sairam, 1982b) and investigations of other species of monkeys (see below). By either method of handling, approximately $30 \%$ of the homogenate protein was recovered in the subcellular fraction sedimenting at $40000 \mathrm{~g}$ (designated fraction P1). Centrifugation of the supernatant of this fraction at $140000 \mathrm{~g}$ for $1 \mathrm{~h}$ did not result in significant recovery of protein $(<2 \%)$ in the small pellet fraction P2.

The specific binding of ${ }^{125} \mathrm{I}$-labelled $\mathrm{hFSH}$ as assessed by incubation at $37^{\circ} \mathrm{C}$ for $2 \mathrm{~h}$ (Text-fig. 1) was proportional to the amount of the testicular protein fraction. Binding to the homogenate $(\mathrm{H} 1)$ was low with maximum specific binding $(\sim 8 \%$ ) occurring in the presence of about $400 \mu \mathrm{g}$ protein. However, binding to the P1 fraction was about 2- to 3-fold greater than homogenate. Little or no FSH binding activity was detectable in the $\mathrm{P} 2$ fraction.

The subcellular distribution of protein in the different fractions of monkey testes is compared in Table 1. The pattern of protein yield was approximately the same in the adult testes. The relative ${ }^{125}$ I-labelled hFSH binding in the P1 fraction was 2-3 fold greater (data not given) than that in the respective homogenates, a result identical to that observed for the rhesus monkey testes (Text-fig. 1).

The specific binding of ${ }^{125}$ I-labelled hFSH to $50 \mu \mathrm{g}$ of the Pl fraction from the 4 species was proportional to the amount of the labelled hormone added to the incubation mixture. Specific 


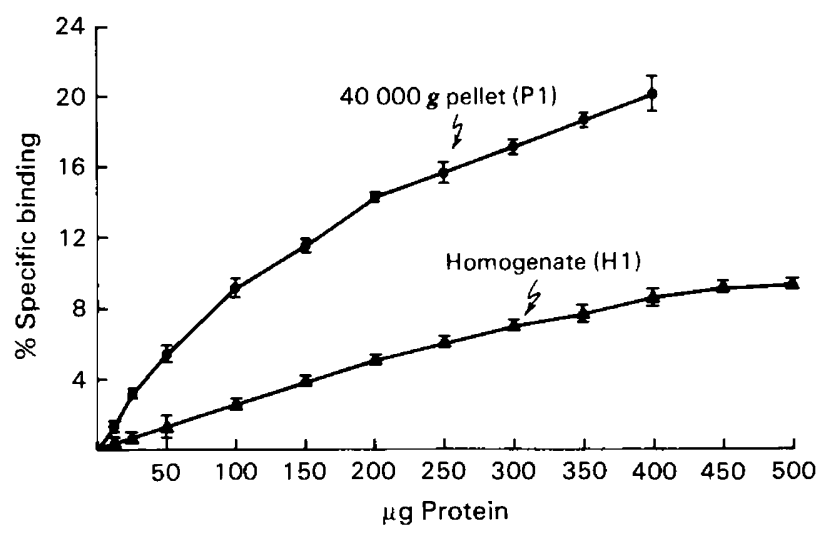

Text-fig. 1. Specific binding of ${ }^{125}$ I-labelled hFSH to various amounts of testicular fractions from the rhesus monkey. Similar results were obtained with tissue from the other 3 species. The total volume of incubation was $250 \mu \mathrm{l}$ which was incubated at $37^{\circ} \mathrm{C}$ for $2 \mathrm{~h}$. Non-specific binding was determined in each case in the presence of $100 \mathrm{ng}$ unlabelled $\mathrm{hFSH}$. The values are mean \pm s.d. for 3 determinations.

Table 1. Comparison of subcellular protein distribution (mg protein/g tissue) in the testes of 4 species of primate

\begin{tabular}{lcccc}
\hline & $\begin{array}{c}\text { Rhesus } \\
\text { macaque }\end{array}$ & $\begin{array}{c}\text { Pig-tailed } \\
\text { macaque }\end{array}$ & $\begin{array}{c}\text { Crab-eating } \\
\text { macaque }\end{array}$ & $\begin{array}{c}\text { Yellow } \\
\text { baboon }\end{array}$ \\
\hline Age (years) & $>5$ & $>5$ & $>5$ & $>5$ \\
Testicular wt $(\mathrm{g}) *$ & $18.3 \pm 2.0$ & $15.1 \pm 1.6$ & $12.6 \pm 1.0$ & $14.1 \pm 3.7$ \\
Subcellular fractions & & & & \\
Homogenate $(\mathrm{H} 1)$ & $39.3 \pm 0.57$ & $30.4 \pm 4.31$ & $30.0 \pm 0.30$ & $32.7 \pm 1.46$ \\
$40000 \mathrm{~g}$ pellet $(\mathrm{P} 1)$ & $11.8 \pm 0.67$ & $11.6 \pm 0.97$ & $10.9 \pm 1.73$ & $11.2 \pm 1.32$ \\
$140000 \mathrm{~g}$ pellet $(\mathrm{P} 2)$ & $0.6 \pm 0.06$ & $0.5 \pm 0.08$ & $0.5 \pm 0.06$ & $0.3 \pm 0.05$ \\
\hline
\end{tabular}

Values are mean \pm s.e.m. for 4-6 tissue samples homogenized mechanically.

* After decapsulation.

binding was linear at low hormone concentrations with saturation of binding sites occurring between 1500 and $5300 \mathrm{pg}{ }^{125}$ I-labelled hFSH (50-177 fmol).

Analysis of the binding data by Scatchard plot (Scatchard, 1949) yielded the dissociation constant and the binding capacity. The dissociation constants for the 4 species $\left(2 \cdot 2-3.0 \times 10^{-10} \mathrm{M}\right)$ were similar to that of the bull testicular FSH receptor. The binding capacity per testis was in the range of $0.82-1.6 \mathrm{pmol} /$ testis (Table 2 ).

Table 2. Binding characteristics of FSH receptor ( $\mathrm{Pl}$ fraction) from testes of adult monkeys

\begin{tabular}{lccc}
\hline & $\begin{array}{c}\text { No. of } \\
\text { tissues } \\
\text { used }\end{array}$ & $\begin{array}{c}K_{\mathrm{d}} \\
\text { Dissociation } \\
\text { constant }\left(\times 10^{10} \mathrm{M}\right)\end{array}$ & $\begin{array}{c}n \\
\text { Binding sites } \\
\text { (pmole/g testis) }\end{array}$ \\
\hline Rhesus macaque & 9 & $3.03 \pm 0.14$ & $1 \cdot 14 \pm 0.17$ \\
Pig-tailed macaque & 3 & $2 \cdot 17 \pm 0.36$ & $0.82 \pm 0.18$ \\
Crab-eating macaque & 3 & $2 \cdot 51 \pm 0.37$ & $1 \cdot 58 \pm 0.29$ \\
Yellow baboon & 4 & $2.36 \pm 0.34$ & $1 \cdot 17 \pm 0.17$ \\
Bull & 4 & $2.03 \pm 0.28$ & $0.62 \pm 0.02$ \\
\hline
\end{tabular}

Values are mean \pm s.e.m. and do not account for the effects of freezing so may represent an underestimate. 


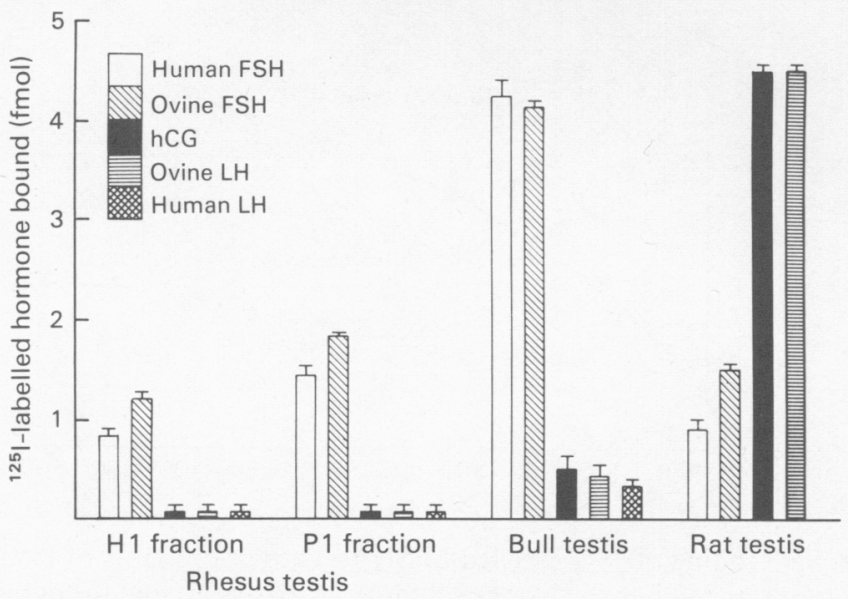

Text-fig. 2. Relative binding ability of ${ }^{125}$ I-labelled human gonadotrophins (hCG, hLH, hFSH) and sheep gonadotrophins (LH and FSH) to testicular fractions from the rhesus monkey, adult bull and adult rat. In each test an equivalent of $100 \mu \mathrm{g}$ protein was incubated with the labelled hormones for $3 \mathrm{~h}$ at $37^{\circ} \mathrm{C}$. The specifically bound hormone is represented as fmol (for the calculations the molecular weight of hCG was taken to be 36700 and that of LH and FSH to be 30000 each). The binding patterns of labelled hormones to fractions from the other 3 species of monkeys were similar to those for the rhesus testes (data not shown). Each bar shows mean \pm s.e.m. $(n=3)$. Non-specific binding was determined in the presence of $100 \mathrm{ng}$ of the respective unlabelled hormones.

\section{Effect of freezing and freeze-drying on the receptor}

The binding of ${ }^{125} \mathrm{I}-$ labelled hFSH to the receptor (P1 fraction) immediately after preparation and following freezing, at $-70^{\circ} \mathrm{C}$ for 2 days -7 months, and freeze drying was assessed. In all 4 species studied, the degree of ${ }^{125}$ I-labelled hFSH binding to the receptor was slightly decreased (about $20 \%$ ) after 2 days of freezing at $-70^{\circ} \mathrm{C}$ and thawing. The decrease appeared to be greater $(30 \%)$ in crab-eating macaque testes which had low initial binding. In yellow baboons, the frozen and thawed receptor still showed very good $(20 \%)$ specific binding.

\section{Hormone specificity of rhesus monkey testicular fractions}

The specificity of binding of various ${ }^{125}$ I-radiolabelled hormones (human and non-human) to testicular fractions derived from the rhesus monkey, bull and rat is illustrated in Text-fig. 2. Binding of ${ }^{125} \mathrm{I}$-labelled hFSH and oFSH was observed with fractions $\mathrm{Hl}$ and $\mathrm{Pl}$ of rhesus monkey testis, with the P1 fraction showing greater binding. However, the rhesus monkey receptor preparations bound very little labelled primate LH ( ${ }^{125} \mathrm{I}$-labelled hCG or ${ }^{125} \mathrm{I}$-labelled $\mathrm{hLH}$ ) or nonprimate LH ( ${ }^{125} \mathrm{I}$-labelled oLH). Incubation of ${ }^{125} \mathrm{I}$-labelled hCG with up to $900 \mu \mathrm{g}$ fraction P1 did not result in more than $1 \%$ specific binding of the hormone. This should be compared with $16-20 \%$ specific binding of ${ }^{125}$ I-labelled hFSH observed with $300-400 \mu \mathrm{g}$ of the P1 fraction.

\section{Specificity of the primate FSH receptor}

In a binding assay using receptor fraction $\mathrm{P} 1$ from the monkey testicular preparations, the binding of ${ }^{125}$ I-labelled hFSH was effectively inhibited by unlabelled hFSH in a dose dependent manner. The nature of displacement curves obtained with the receptor from all the four species were similar (Text-fig. 3). The competition between ${ }^{125}$ I-labelled hFSH and various amounts of unlabelled FSH from different species for specific binding to the receptor fraction $\mathrm{P} 1$ is shown in 


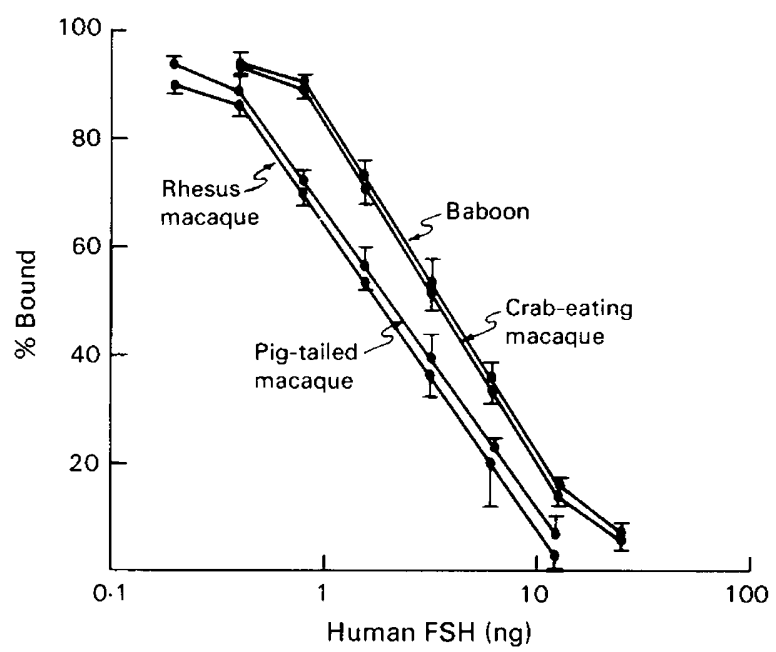

Text-fig. 3. Competition between ${ }^{125}$ I-labelled hFSH and unlabelled hFSH for binding sites in the testicular fractions from the 4 species of monkey. Receptor protein equivalent to $7-17 \mathrm{mg}$ wet weight of testis was incubated with 50000 c.p.m. ${ }^{125} \mathrm{I}$-labelled $\mathrm{hFSH}$ for $2 \mathrm{~h}$ at $37^{\circ} \mathrm{C}$ and the amount of radioactivity specifically bound in the presence of different amounts of unlabelled hFSH was determined. Non-specific binding was determined in the presence of $100 \mathrm{ng} \mathrm{hFSH}$. The total specifically bound in each instance varied from 7 to $12 \%$ of the added radioactivity and was normalized to $100 \%$ for comparison.

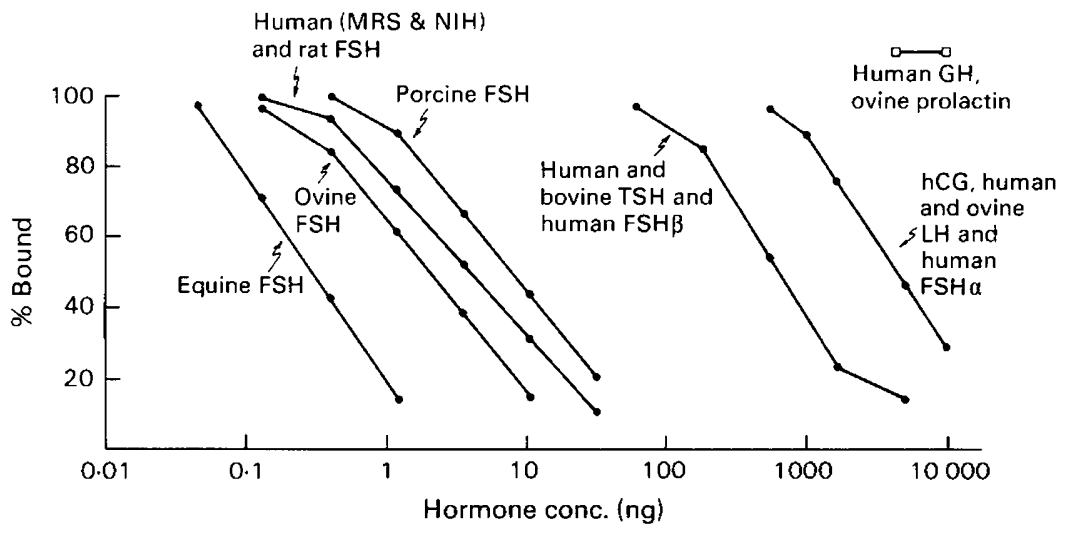

Text-fig. 4. Interaction of primate testicular FSH receptor with heterologous FSH. Data derived from the rhesus monkey $P 1$ receptor fraction is depicted as an example. Identical results were obtained with all the other 3 species. The conditions of incubation were the same as shown in Text-figure 3 . The amount of ${ }^{125} \mathrm{I}$-labelled $\mathrm{hFSH}$ specifically bound was considered as $100 \%$. For calculation of relative potencies the amount (ng) of unlabelled hFSH for $50 \%$ displacement was regarded as $100 \%$ activity, and the following potency estimates were obtained (average of 2 assays): equine, $1125 \%$; ovine, $222 \%$; rat, $100 \%$; porcine, $45 \%$; hTSH, bTSH, hFSH $\beta, 0.7 \%$, hCG, hLH, oLH, hFSH $\alpha, 0.08 \%$, hCG, ovine prolactin, LHRH, no displacement at 1-10 $\mu \mathrm{g}$. Human FSH-MRS denotes hormones prepared in our laboratory; human FSH-NIH hormone supplied by NIH. The computed slopes of the displacement curves were as follows: equine FSH, 2.2 ; ovine FSH, 2.31 ; human FSH (MRS and NIH) and rat FSH, $2 \cdot 2$; porcine FSH, $2 \cdot 2$; bovine TSH, human TSH and human FSH $\beta, 2 \cdot 7$; hCG, human LH and human $\mathrm{FSH} \alpha, 2 \cdot 7$. 
(Text-fig. 4) with rhesus monkey receptor as an example. The results obtained with the other 3 primate receptors were identical in all respects. All unlabelled $\mathrm{FSH}$ preparations from human as well as non-primate pituitaries were effective in competing for binding sites in a dose-dependent manner. The order of displacement curves in an assay using ${ }^{125} \mathrm{I}$-labelled hFSH and a bovine testicular receptor was similar to data shown in Text-fig. 4. The displacement curves for all five FSH preparations investigated were not significantly non-parallel. Equine FSH was the most potent in the competition assay, showing about ten times the activity of the hFSH prepared either in our own laboratory or that supplied by NIH. Porcine FSH was slightly less active than hFSH. While the monkey FSH receptor was not species-specific with respect to the ligand, it was highly hormone specific. As shown in Text-fig. 4, highly purified hCG, hLH, pLH and hFSH $\alpha$ competed only at extremely high concentrations (potency $<0 \cdot 1 \%$ of $\mathrm{hFSH}$ ); hGH and ovine prolactin and LHRH were ineffective. The inhibition observed with the human and bovine TSH preparations and $\mathrm{hFSH} \beta$ (calculated potency $<0.8 \%$ of hFSH) might be due to some intrinsic activity or trace contamination with FSH. The rhesus monkey Pl fraction, after 7 months of freezing at $-70^{\circ} \mathrm{C}$ or freeze-drying, gave identical displacement patterns with the different FSH preparations.

\section{Discussion}

Gonadotrophin binding sites of high affinity for FSH have been demonstrated in cell homogenates, particulate fractions or partly purified solubilized fractions of rat, bull and boar testes (Means \& Vaitukaitis, 1972; Bhalla \& Reichert, 1974; Cheng, 1975a, b; Abou-Issa \& Reichert, 1977; Rogister et al., 1978). At the time we began our studies, no data were available in the literature on the interaction of primate testes with FSH at the cellular level. We have now identified a particulate fraction in the monkey testis which can specifically bind hFSH. The ${ }^{125} \mathrm{I}$-labelled $\mathrm{hFSH}$ bound well to the particulate fraction from the testes of all 4 species investigated.

The high cost and rarity of the non-human primates for laboratory studies impose serious constraints on the choice of tissues for receptor studies. Fresh tissues are not easily available. However, as demonstrated in the present work, frozen tissues are suitable for the preparation and characterization of primate FSH receptors. As there may be some small initial loss after freezing, our estimates of the FSH binding capacity of the different species may have been slightly underestimated.

Although the $\mathrm{LH} / \mathrm{hCG}$ receptor in the primate testis (Davies et al., 1979) and human (Cole et al., 1976) and monkey (Cameron \& Stouffer, 1981) corpus luteum is species specific, the FSH receptor from the monkey testis is not: many unlabelled heterologous FSH preparations (equine, ovine, porcine, rat) competed as effectively as or better than hFSH for binding sites (Text-fig. 4) and ${ }^{125}$ I-labelled ovine FSH also bound well to the monkey receptors (Text-fig. 4). Human corpora lutea (Cole et al., 1976) frozen at $-20^{\circ} \mathrm{C}$ for 3-21 months showed a tendency to lose species specificity by interacting with heterologous LH while retaining high specificity for human $\mathrm{LH} / \mathrm{hCG}$ when the studies were done with fresh tissue. Such a change is unlikely to have occurred with the monkey testis because a particulate fraction from freshly removed testes from the bonnet monkey (Macaca radiata) interacts with FSH from several species (M. R. Sairam, A. J. Rao, N. R. Moudgal \& M. I. Berman, unpublished results). It is possible that the primate FSH receptor is different from the $\mathrm{LH}$ receptor as far as its species specificity is concerned, with the latter exhibiting a more strict requirement for primate hormones. Our data, on the interaction of heterologous FSH with primate FSH receptor, agree well with data reported in the literature. Several studies have shown that adenohypophysial extracts derived from a variety of species (sheep, pig, horse, human) were able to induce an increase in the size of human and non-primate ovaries, due to an enormous enlargment of the follicles with little or no trace of luteinization (Hartman \& Squier, 1931; Hisaw, Fevold \& Leonard, 1931; Hisaw, Hertz \& Fevold, 1936; Knobil, Kostyo \& Greep, 1959; Jones, Aziz \& Urbina, 1961). While FSH receptors have been 
demonstrated in the primate ovary (Peluso, Steger, Jaszczak \& Hafez, 1976) the species specificity of the receptor has not been determined. Data on the effects of heterologous gonadotrophins in monkey testis are scanty. Reports such as that of Greep (1937) indicated enlargement of gonads of immature animals after treatment with non-human pituitary fractions containing FSH. The marked enlargement of seminiferous tubules and Sertoli cell cytoplasm noted in immature rhesus monkeys following oFSH or PMSG treatment (Arslan et al., 1981) clearly indicates a lack of species specificity in hormone interaction, consistent with our observations (Text-fig. 4).

The adult monkey testis is similar to the bull in having more FSH receptors than $\mathrm{LH}$ receptors and both of these differed from the rat which showed a reverse trend in this respect (see Text-fig. 2). The failure to detect significant LH binding could not have been due to the loss of integrity of the labelled hormone because these preparations showed good specific binding to a rat testicular preparation (Text-fig. 2). Gentle hand homogenization has been reported to yield particulate fractions of primate testis with some hCG binding ability (Davies et al., 1979). It was therefore possible that our inability to detect significant LH binding sites in the adult rhesus monkey tissues used was due to our method of membrane preparation. Gentle homogenization by hand in a tissue grinder and rougher mechanical dispersion gave approximately the same amount of ${ }^{125} \mathrm{I}$ labelled hFSH binding, but there was no significant ${ }^{125} \mathrm{I}$-labelled hCG or hLH binding. Our inability to demonstrate significant binding of ${ }^{125}$ I-labelled hCG or LH in the rhesus monkey tissue could have been due to the loss of the very low amount of these receptors in the mature testes during the period when they were kept frozen. In contrast with our data, Davies et al. (1979) detected small levels of binding sites with tissue derived from monkeys designated as being greater than 6 years old. Besides the fact that we studied frozen tissues, other factors such as age and variation in reproductive activity could have contributed to the differences in these results. The rhesus monkey is reported to be a seasonal breeder even under laboratory conditions, showing cyclic variations in hormonal profiles, testicular size and activity (Wickings \& Nieschlag, 1980). Most of the tissues we studied, except those of the baboon, were removed from animals in the summer months, a time when the seasonal cycle is apparently at a nadir.

This investigation was supported by the M.R.C. of Canada. The procurement of primate tissues used in this study was made possible through a grant (NIH RR00166) to the University of Washington Primate Center. We also thank Dr R. P. Michael, Emory University, for providing monkey testes; Dr C. H. Li, Dr J. G. Pierce, Dr R. J. Ryan, Dr T. Landefeld and the NIH for gifts of hormones; and Nicole Valiquette for assistance with the preparation of this manuscript.

\section{References}

Abou-Issa, H. \& Reichert, L.E., Jr (1977) Solubilization and some characteristics of the follitropin receptor from calf testis. J. biol. Chem. 252, 4166-4174.

Arslan, M., Zaidi, P., Akhtar, F.B., Amin, S., Rana, T. \& Qzai, M.H. (1981) Effects of gonadotrophin treatment in vivo on testicular function in immature rhesus monkeys (Macaca mulatta). Int. J. Androl . 4, 462-474.

Berman, M.I. \& Sairam, M.R. (1982a) Characterization of primate testicular FSH receptor. Ann. N.Y. Acad. Sci. 383, 426-427.

Berman, M.I. \& Sairam, M.R. (1982b) Studies on primate gonadotropin receptors. Characterization of the particulate $\mathrm{FSH}$ receptor from monkey testis. $J$. clin. Endocr. Metab. 55, 1153-1160.

Bhalla, V.K. \& Reichert, L.E., Jr (1974) Properties of follicle-stimulating hormone-receptor interactions. Specific binding of human follicle-stimulating hormone to rat testes. J. biol. Chem. 249, 43-51.
Cameron, J.L. \& Stouffer, R.L. (1981) Comparison of the species specificity of gonadotropin binding to primate and nonprimate corpora lutea. Biol. Reprod. 25, $568-572$.

Cheng, K.W. (1975a) A radioreceptor assay for follicle stimulating hormone. J. clin. Endocr. Metab. 41, 581589.

Cheng, K.W. (1975b) Properties of follicle stimulating hormone receptor in cell membranes of bovine testis. Biochem. J. 149, 123-132.

Cole, F.E., Weed, J.C., Schneider, G.T., Holland, J.B., Geary, W.L., Levy, D.L., Huseby, R.A. \& Rice, B.F. (1976) The specificity of gonadotropin binding by the human corpus luteum. Fert. Steril. 27, 921-928.

Davies, T.F., Walsh, P.C., Hodgen, G.D., Dufau, M.L. \& Catt, K.J. (1979) Characterization of the primate luteinizing hormone receptor in testis homogenates and Leydig cells. J. clin. Endocr. Metab. 48, 680-685. 
Dufau, M.L. \& Catt, K.J. (1978) Gonadotropin receptors and regulation of steroidogenesis in the testis and ovary. Vitams Horm. 36, 461-592.

Frowein, J. \& Engel, W. (1974) Constitutivity of the hCG-receptor protein in the testis of rat and man. Nature, Lond. 249, 377-379.

Greep, R.O. (1937) Pituitary regulation of the male gonad. Cold Spring Harbor Symp. Quant. Biol. 5, 136141.

Hartman, C.G. \& Squier, R.R. (1931) The folliclestimulating effect of pig anterior lobe on the monkey ovary. Anat. Rec. 50, 267-273.

Hisaw, F.L., Fevold, H.L. \& Leonard, S.L. (1931) Effects of hypophyseal extracts on sexually immature monkeys. Proc. Soc. exp. Biol. Med. 29, 204-206.

Hisaw, F.L., Hertz, R. \& Fevold, H.L. (1936) Experimental production of ovarian refractoriness to anterior hypophyseal stimulation in the monkey. Endocrinology 20, 40-46.

Hsu, A.F., Stratico, D., Hosaka, M. \& Troen, P. (1978) Studies of the human testis. X. Properties of human chorionic gonadotropin receptor in adult testis and relation to intratesticular testosterone concentration. J. clin. Endocr. Metab. 47, 529-536.

Huhtaniemi, I.T., Korenbrot, C.C. \& Jaffe, R.B. (1977) hCG binding and stimulation of testosterone biosynthesis in the human fetal testis. J. clin. Endocr. Metab. 44, 963-967.

Jones, G.S., Aziz, Z. \& Urbina, G. (1961) Clinical use of gonadotropins in conditions of ovarian insufficiency of various etiologies. Fert. Steril. 12, 217-235.

Knobil, E., Kostyo, J.L. \& Greep, R.O. (1959) Production of ovulation in the hypophysectomized rhesus monkey. Endocrinology 65, 487-493.

MadhwaRaj, H.G., Sairam, M.R. \& Nieschlag, E. (1980) Immunological approach to regulation of fertility in the male. In Regulation of Male Fertility, pp. 209-218. Eds G. R. Cunningham, W. B. Schill \& E. S. E. Hafez. Martinus Nijhoff Publ., The Hague.

Means, A.R. \& Vaitukaitis, J. (1972) Peptide hormone "receptors": specific binding of ${ }^{3} \mathrm{H}-\mathrm{FSH}$ to testis. Endocrinology 90, 39-46.

Murty, G.S.R.C., Sheela Rani, C.S. \& Moudgal, N.R. (1980) The role of FSH in regulating testicular function. A study involving the use of specific FSH antibodies. Proc, 6th Int. Congr. Endocrinology, pp. $162-165$.
Peluso, J.J., Steger, R.W., Jaszczak, S. \& Hafez, E.S.E. (1976) Gonadotropin binding sites in human postmenopausal ovaries. Fert. Steril. 27, 789-795.

Rogister, G.M., Closset, J., Combarnous, Y., Hennen, G., Dechenne, C. \& Ketelslegers, J.M. (1978) Study of follitropin receptors in testis using a homologous system. Binding of porcine follitropin to plasma membranes from immature porcine testis and correlation with adenylate cyclase stimulation. Eur. $J$. Biochem. 86, 121-131.

Ryan, R.J. \& Lee, C.Y. (1976) The role of membrane bound receptors. Biol. Reprod. 14, 16-29.

Sairam, M.R. (1976) Role of arginine residues in ovine lutropin: reversible modification by 1,2-cyclohexanedione. Archs Biochem. Biophys. 176, 197-203.

Sairam, M.R. (1979a) Studies on pituitary follitropin. I. An improved procedure for the isolation of highly potent ovine hormone. Archs Biochem. Biophys. 194, 63-70.

Sairam, M.R. (1979b) Evaluation of the bovine testicular radioreceptor assay for pituitary follicle stimulating hormone. J. Endocr. 82, 253-262.

Sairam, M.R. \& Li, C.H. (1979) Studies on pituitary follitropin. V. Isolation of the subunits of the human hormone and reaction of the amino groups with acylating agents. Int. J. Peptide Protein Res. 13, 394402.

Sairam, M.R., Chrétien, M. \& Li, C.H. (1978) On the isolation of human pituitary hormones. J. clin. Endocr. Metab. 47, 1002-1008.

Scatchard, G. (1949) The attractions of proteins for small molecules and ions. Ann. N.Y. Acad. Sci. 51, 660-672.

Sharpe, R.M., Wu, F.C.W. \& Hargreave, T.B. (1980) Binding of human chorionic gonadotrophin to testicular biopsy tissue from infertile men and the effect of prior treatment with human chorionic gonadotrophin. J. Endocr. 86, 117-125.

Thorell, J.I. \& Johansson, B.G. (1971) Enzymatic iodination of polypeptides with ${ }^{125}$ I to high specific activity. Biochim. Biophys. Acta 251, 363-369.

Wickings, E.J. \& Nieschlag, E. (1980) Effects of season on endocrine and exocrine testicular functions of the adult rhesus monkey (Macaca mulatta) maintained under constant laboratory conditions. Int. J. Androl. $3,87-104$. 